\title{
Differential Adjuvant Effects of Soluble Beta Glucans from Barley and Saccharomyches Cerevisia in Primary and Secondary Humoral Immune Responses
}

\author{
Kadriye USLU ${ }^{1}$, E. Umit BAGRIACIK ${ }^{2}$ \\ ${ }^{1}$ Refik Saydam National Public Health Agency \\ ${ }^{2}$ Gazi University Faculty of Medicine, Department of Immunology, Ankara, TURKEY
}

\begin{abstract}
The purpose of this study was to investigate and compare adjuvant effects of soluble B-glucans from barley and Saccharomyches cerevisia in induction of antigen specific humoral immune responses. Mice were immunized with conalbumin at a relatively low concentration in the presence of beta glucans. Anti-conalbumin antibodies in the sera of immunized and control mice were quantified by ELISA. At high doses, both of glucans increased effectively levels of circulating IgM and IgG antibodies which were specific for conalbumin. However, coadministration of glucan from barley at $1 \mathrm{\mu g}$ dose resulted in lower yield in IgG1, IgG2a, IgG2b, and IgA levels in comparison to that of yeast-derived glucan at the same dose. We also found that antigen (conalbumin) specific antibody levels enhanced by B-glucan from Saccharomyches cerevisia were always higher than those of the glucan from barley. Based on these findings, we concluded that (1,3),(1,6)-B-D-glucan from yeast cell wall might have superior immunostimulant activity in induction of antigen specific humoral immune responses over (1,3), (1,4)- B-D-glucan from barley.
\end{abstract}

Keywords: (1,3),(1,6)- B-D-glucan; (1,3),( 1,4)- B-D-glucan; adjuvant; humoral immunity.

ÖZET

Saccharomyches cerevisia ve Arpadan Elde Edilen Beta Glukanların Primer ve Sekonder Hümoral İmmün Cevaptaki Farklı Adjuvan Etkisi

Bu çalıșmanın amacı antijene özgül hümoral immün cevabın oluşması sırasında arpa ve Saccharomyches cerevisia'dan elde edilen çözünebilir ß-glukanların adjuvan etkilerinin araştııımasıdır. Fareler beta glukan varlı̆̆ında göreceli olarak düşük dozlarda konalbümin ile immünize edildi. İmmünize edilmiş ve edilmemiş kontrol fare serumunda anti-konalbumin antikorları ELISA yöntemi ile tayin edildi. Yüksek dozlarda uygulandığı zaman her iki glukan konalbümine özgül lgM ve lgG antikor seviyelerini etkin bir şekilde arttırdı. Ancak, aynı dozda maya (Saccharomyches cerevisia) kökenli glukan ile karşısştııılığında, konalbümin ve $1 \mu \mathrm{g}$ arpadan elde edilen glukanın birlikte enjeksiyonu, daha düşük seviyelerde lgG1, IgG2a, IgG2b, and lgA üretimine neden oldu. Saccharomyches cerevisia kökenli glukan tarafından artııılan antijene özgül antikor seviyeleri, arpa kökenli glukan tarafından arttıılan antijene özgül antikor seviyelerinden daima daha fazla oldu. Bu sonuçlar temel alınarak antijene özgül hümoral immün yanıt oluşmasında, mayadan elde edilen $(1,3),($ 1,6)-B-D-glukanın, arpadan elde edilen (1,3),( 1,4)- b-D-glukan'a göre daha fazla immünostimülan aktiviteye sahip olduğu düşünülebilir.

Anahtar Kelimeler: (1,3),(1,6)- B-D-glukan; (1,3),( 1,4)- B-D-glukan; adjuvan; hümoral immünite 


\section{INTRODUCTION}

Beta glucans are branched glucose polymers which are commonly found in yeast, plants, and some other organisms as structural components of the cell wall. They have a backbone of $B(1 \rightarrow 3)$-linked $B$-D-glucopyranosyl units with either $\beta(1 \rightarrow 6)$ linked side chains as in Saccharomyches cerevisiae or $B(1 \rightarrow 4)$ linked side chains as in barley. ${ }^{1-3}$ Extensive studies concerning their immunomodulatory role particularly on the innate immune system have been accomplished so far..$^{4-5}$ However, characteristics of specific antibody responses augmented by $ß$-glucans with different features have been poorly understood.

Several studies have reported that $\beta$-glucans extracted from oat and S. cerevisiae increased anti-bacterial and anti-parasitic activity of the immune system thereby enhancing resistance to parasitic and bacterial infections..$^{6-9}$ The others have shown anti-cancer properties of $\beta$-glucans in studies of murine tumor models. For example, ß-glucan-mediated tumoricidal activity was related to elevated levels of tumor specific antibody-dependent cell-mediated cytotoxicity. ß-glucans could bind to complement receptor 3 (CR3) and B-glucan-primed CR3 bearing leukocytes could kill iC3b-opsonized tumor cells. ${ }^{10-14}$ None of these studies evaluated or compared different B-glucans for their biological effects in antigen specific humoral immune responses.

There have been some confusions and controversies in immunostimulatory activities of $\beta$-glucans due to the investigations of a variety of $\beta$-glucans. For example, ß-glucans with different molecular weight, different chemical or physical modifications, and different origins have been studied for their ability in stimulation of the immune system. These contradictory results need to be systematically evealuated and resolved. To clerify those isssues at least in part, in this study we aimed at comparing adjuvant activity of soluble $\beta$-glucans from barley and S. cerevisiae. Antigen specific antibody responses that were enhanced by those $\beta$-glucans were characterized.

\section{MATERIALS and METHODS}

Animals and B-glucans: Swiss albino mice were obtained from Refik Saydam National Public Health Agency (RSNPHA) animal laboratories in Ankara, Turkey. Mice were maintained under conventional

\begin{tabular}{|lll|}
\hline \multicolumn{3}{|l|}{ Table 1. Physical characteristics of soluble beta glucans. } \\
\hline Characteristic & S. cerevisiae & Barley \\
\hline Purity & $90 \%$ & $96 \%$ \\
MWa & $200,000 \mathrm{~b}$ & $260,000 \mathrm{~b}$ \\
Glycosidic Linkeage & $1,3-, 1,6-B e t a-D$ & $1,3-, 1,4-$ Beta-D \\
Protein & $0.1 \%$ & $0.4 \%$ \\
Arabinoxylan & - & $<0.3 \%$ \\
Starch & - & $<0.1 \%$ \\
Viscosity & - & Medium \\
\hline a: molecular weight & & \\
b: Dalton & \\
\hline
\end{tabular}

animal facility conditions at the vivarium of RSNPHA. The experimental protocol was approved by the local animal care ethical committee at Gazi University.

Commercially available B-glucans were purchased from Megazyme International Ltd. Ireland Co (Cata$\log$ No: P-BGBM, and P-BGYST, Wicklow, Ireland). Detailed information for the physical and chemical characteristics of glucans are shown in Table 1. As instructed glucan from barley was boiled in $95 \%$ ethanol for 10 minutes while stirring until completely dissolved.

Immunization schedule and process of blood specimens: Eight to 10 week-old female mice were challenged by intraperitoneal injections of $10 \mu \mathrm{g}$ conalbumin (CA, Catalog No: C-0755, Sigma, St. Lewis, USA) in the presence of beta glucans at indicated concentrations. Five mice per group were used. The day of the first injection was taken as the day zero. For the secondary responses, mice, which were challenged with conalbumin on the day zero were rechallenged in the presence or absence of beta glucans at the indicated concentrations on the seventh day. Blood was collected on the 7th day for primary responses and 14th day following immunizations for the secondary responses. Blood specimens were centrifuged at $2000 \mathrm{rpm}$ Serum samples pooled for each group of mice were frozen at $-80^{\circ} \mathrm{C}$ until use.

ELISA for Immunoglobulin typing: Determination of $\operatorname{IgM}, \operatorname{IgA}$ and $\operatorname{IgG}$ subtypes were assessed by using a commercially available immunoglobulin sub-typing ELISA kit according to the manufactu- 
rer's recommendations (Catalog No: K70000, QED Bioscience Inc. San Diego, CA, USA). Briefly, wells of microtiter plate were coated with conalbumin overnight at $4^{\circ} \mathrm{C}$. Serum specimens were diluted at $1: 1,000,1: 10,000$, and 1:1,100,000 ratios in PBS. Each dilution for each specimen was assayed in triplicates. Serum specimens were incubated in conalbumin-coated wells for one hour at room temperature. Following a washing step, horse radish peroxidase (HRP)-labeled anti-mouse subtypes of immunoglobulin antibodies were used individually. Color change was measured at $450 \mathrm{~nm}$ using a microtiter reader (Synergy HT, BioTek, Winooski, VT, USA).

Statistics: SPSS software package was used for statistics. Importance of differences in antibody responses at various doses was calculated by one-way analysis of variance (ANOVA). Independent samples $t$ test was used for calculations of independent samples (groups of two). Levels of differences in groups of more than two (multiple groups, for example, groups of three) was calculated by using LSD (Post Hock). $p<0.05$ was considered statistically significant in all cases.

\section{RESULTS}

\section{Primary responses}

Animal sera collected from immunized mice on the 7th day after the first antigenic challenge were diluted. IgM responses were determined by ELISA. Conalbumin plus barley $\beta$-glucan $(1000 \mu \mathrm{g})$ coadmi-

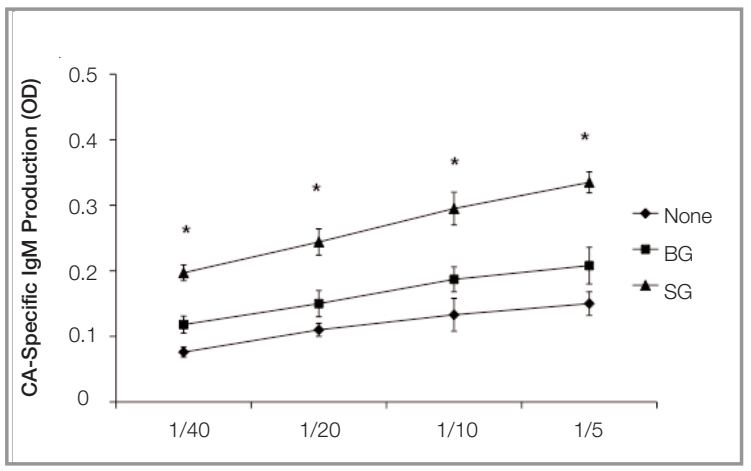

Figure 1. Immunomodulatory effects of ß-glucans on primary humoral immune responses to conalbumin. Mice challenged with $10 \mu \mathrm{g}$ conalbumin were injected i.p. by $1000 \mu \mathrm{g}$ B-glucans either from barley (BG) or from S. cerevisiae (SG). Primary antibody responses were compared to the control mice that received conalbumin alone. ${ }^{*} p<0.05$.

nistration elevated conalbumin-specific IgM responses moderately, thought significant $(\mathrm{p}<0.05)$, in comparison to the mice that received conalbumin alone (Figure 1). However, as seen at each dilution, conalbumin plus S. cerevisiae B-glucan $(1000 \mu \mathrm{g})$ inceased specific IgM responses quite significantly ( $p$ $<0.05$ ) in comparison to both mice that were challenged by antigen plus barley B-glucan or by antigen alone (Figure 1). These results showed that $\beta$-glucan from $\mathrm{S}$. cerevisiae had relatively higher adjuvant effect than that of $\beta$-glucan from barley in generation of antigen-specific primary humoral immune responses.
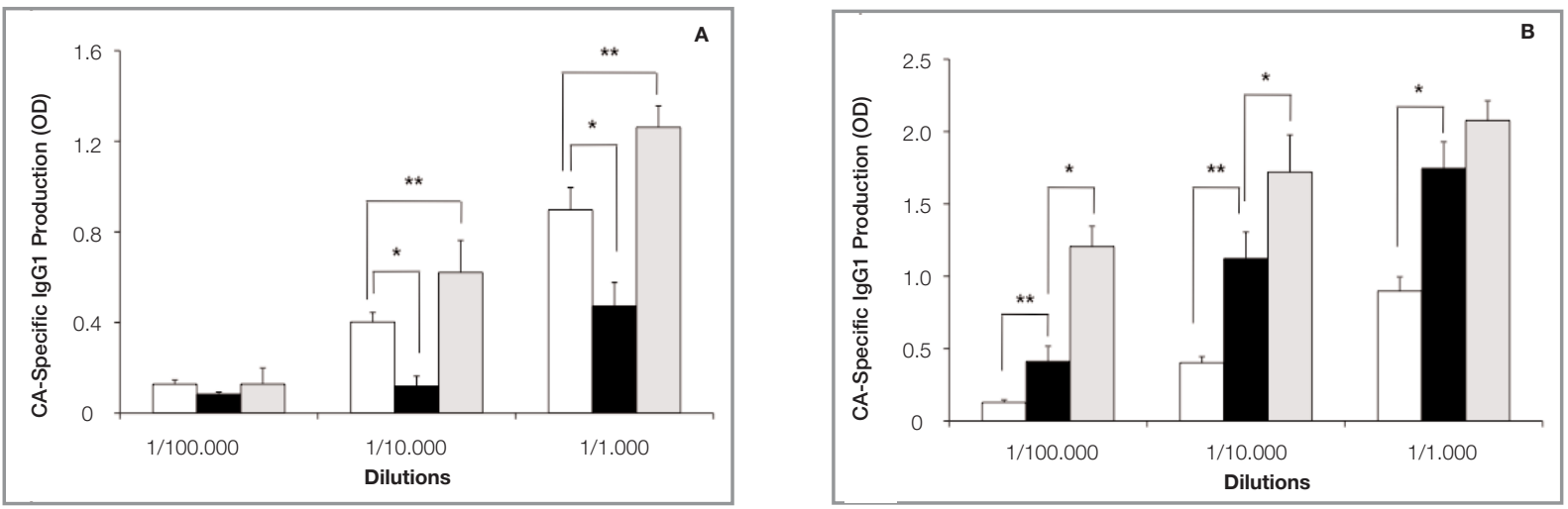

Figure 2. Adjuvant effects of soluble B-glucans on IgG1 responses to conalbumin (CA). Adjuvant activity of S. cerevisiae-derived and barley-derived B-glucan that were co-administered at $1 \mu \mathrm{g}$ (A). Adjuvant activity of S. cerevisiae-derived and barley-derived Bglucan that were co-administered at $1000 \mu \mathrm{g}$ (B). ${ }^{*} \mathrm{p}<0.05$. White: None, Black: BG, Gray: SG. 

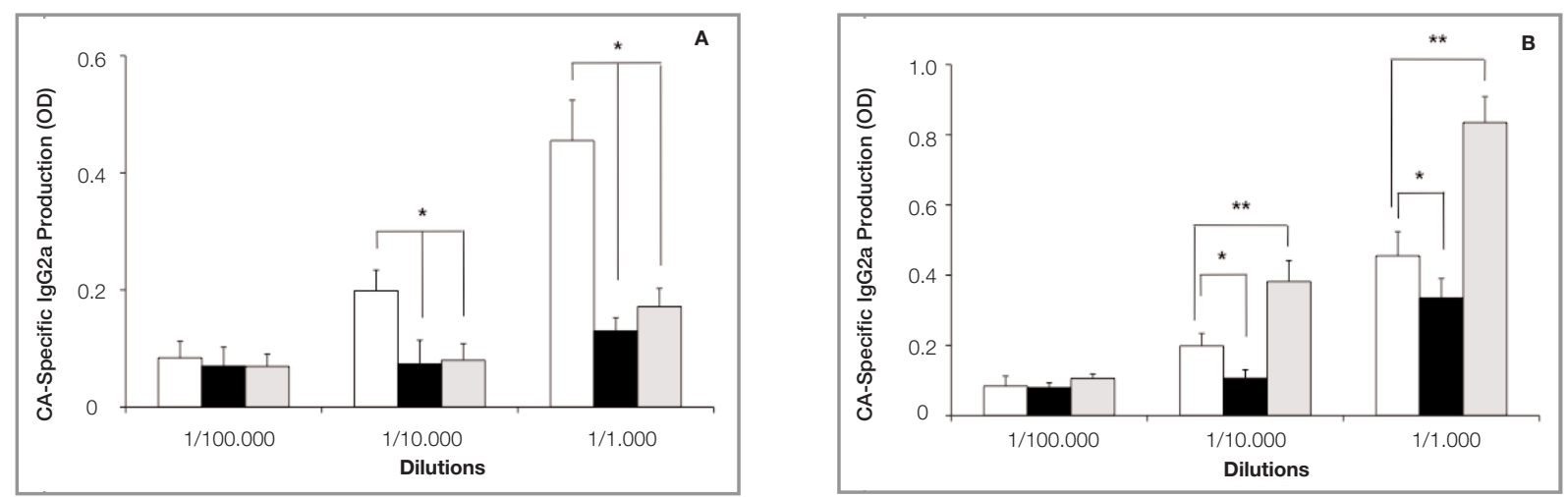

Figure 3. Adjuvant effects of soluble B-glucans on IgG2a responses to conalbumin (CA). Adjuvant activity of S. cerevisiae-derived and barley-derived B-glucan that were co-administered at $1 \mu \mathrm{mg}$ (A). Adjuvant activity of S. cerevisiae-derived and barley-derived Bglucan that were co-administered at $1000 \mu \mathrm{g}$ (B). ${ }^{*} \mathrm{p}<0.05$. White: None, Black: BG, Gray: SG.

\section{Determination of IgG subclasses}

In the next step, we tested adjuvant activity of $\beta$-glucans in the secondary humoral immune responses. To find wheather treatment with B-glucans had any effects on the distribution of IgG subtypes that arose following antigenic challenge, we determined $\mathrm{CA}$ specific IgG1, IgG2a, IgG2b, and IgG3 responses after intraperitoneal antigenic challenge in the presence or absence of B-glucans either from barley or from S. cerevisiae. Serum samples were collected at indicated times as mentioned in the immunization schedule.

S. cerevisiae-derived $B$-glucan significantly $(\mathrm{p}<$ 0.05 ) increased conalbumin (CA)-specific IgG1 response as evident by the existence of CA-specific antibodies even at high dilutions of serum such as 1:1000 and 1:10,000 (Figure 2). We observed a dosedependent effect of S. cerevisiae-derived B-glucan. One $\mu \mathrm{g}$ dose elevated antigen (CA) specific responses slightly while $1000 \mu \mathrm{g}$ dose of the same $B$-glucan increased the conalbumin-specific IgG1 response by several fold in comparison to either the control mice or to the mice that received $1 \mu \mathrm{g} B$-glucan (Figure 2A and $2 \mathrm{~B}$ ). These results showed that $\mathrm{S}$. cerevisiae-derived soluble $B$-glucan exerted its adjuvant activity in a dose-dependent manner.

In contrast to $1 \mu \mathrm{g}$ dose of yeast-derived glucan, $1 \mu \mathrm{g}$ barley-derived $\beta$-glucan decreased conalbumin-specific IgG1 response at a significant level (Figure 2A) when compared to the control mice that received the antigen alone. However, $1 \mu \mathrm{g}$ dose of yeast-derived glucan increased CA-specific IgG1 response significantly $(p<0.05)$. Figure 2B showed that both glucan increased CA-specific IgG1 responses at the dose of $1000 \mu \mathrm{g}$ (Figure 2B). It was obvious that adjuvant activity of yeast-derived $\beta$-glucan was superior to that of barley-derived ß-glucan at all doses and in all serum dilutions tested.

Interestingly, antigen-specific antibodies of $\operatorname{IgG} 2 \mathrm{a}$ subclass were decreased by both of yeast- and barley-derived $\beta$-glucans at $1 \mu \mathrm{g}$ dose comparing to to the control mice immunized with conalbumin alone (Figure 3A). CA-specific IgG2a levels did not increase even after administration of the barley glucan at $1000 \mu \mathrm{g}$. On the other hand, $1000 \mu \mathrm{g}$ yeast-derived B-glucan increased CA-specific IgG2a subclass antibodies significantly (Figure 3B, $p<0.05$ ). We observed similar effects of both glucans on CA-specific IgG2b subclass antibodies as well. Co-administration of both glucans at $1 \mu \mathrm{g}$ decreased IgG2b subclass antibodies (Figure 4A). The decrease caused by barleyderived glucan was particularly important $(\mathrm{p}<0.05)$. Yeast-derived glucan at high concentration elevated CA-specific responses of $\operatorname{IgG} 2 \mathrm{~b}$ subclass whereas $1000 \mu \mathrm{g}$ barley-derived B-glucan did not (Figure 4B). We observed almost no response of CA-specific IgG3 subclass antibody when mice were challanged with either conalbumin alone or in the presence of each glucan (data not shown). The major subtype of antigen specific $\operatorname{IgG}$ was $\operatorname{IgG} 1$, and antigen specific IgG subclass distribution was IgG1 IgG2a IgG2b IgG3 (data not shown). 

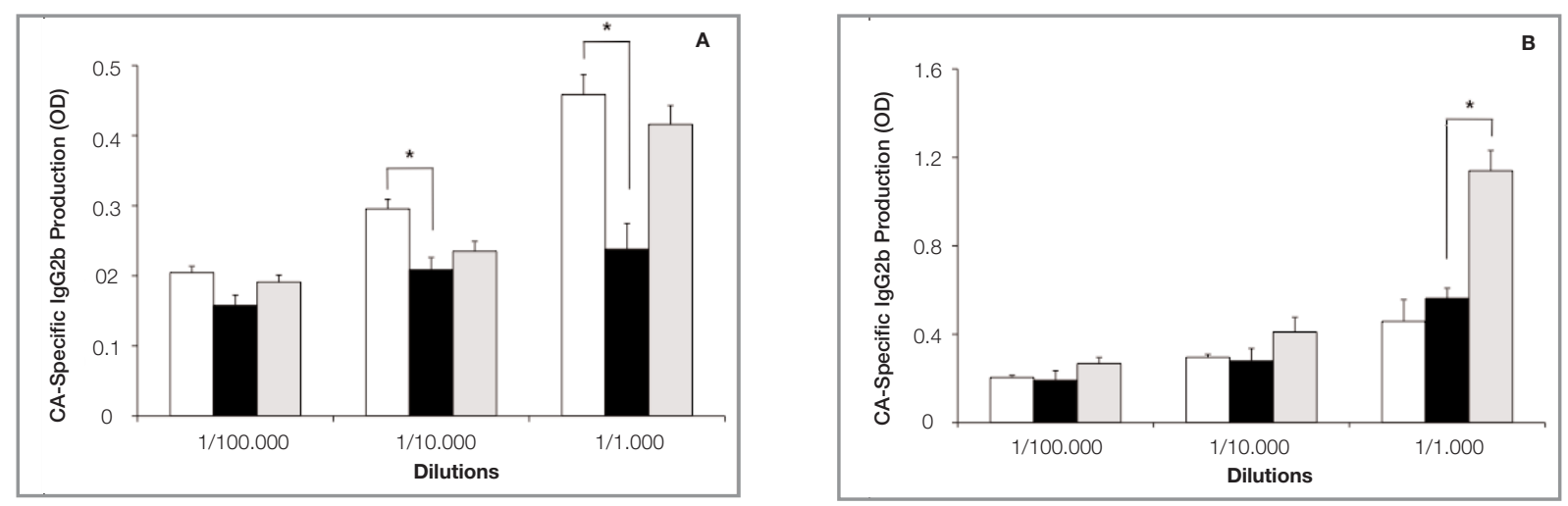

Figure 4. Adjuvant effects of soluble B-glucans on IgG2b responses to conalbumin (CA). Adjuvant activity of S. cerevisiaederived and barley-derived B-glucan that were co-administered at $1 \mu \mathrm{g}(\mathbf{A})$. Adjuvant activity of S. cerevisiae-derived and barleyderived B-glucan that were co-administered at $1000 \mu \mathrm{g}$ (B). ${ }^{*} \mathrm{p}<0.05$. White: None, Black: BG, Gray: SG.

\section{Determination of IgA responses}

B-glucan from S.cerevisiae increased CA-specific $\operatorname{IgA}$ responses at both low and high concentrations (Figure 5A and 5B). However, barley-derived glucan decreased CA-specific IgA responses significantly (Figure 5A). In contrast the co-administration of the barley-derived glucan at low level, $1000 \mu \mathrm{g}$ (high level) dose increased IgA responses at important levels (Figure 5B, $\mathrm{p}<0.05$ ). These results indicated that $\mathrm{B}$ glucans improved mucosal immunity very effectively.

\section{DISCUSSION}

In this study, two soluble $\beta$-glucans from barley and S. cerevisiae were compared for their adjuvant activity modulating antigen specific humoral immune

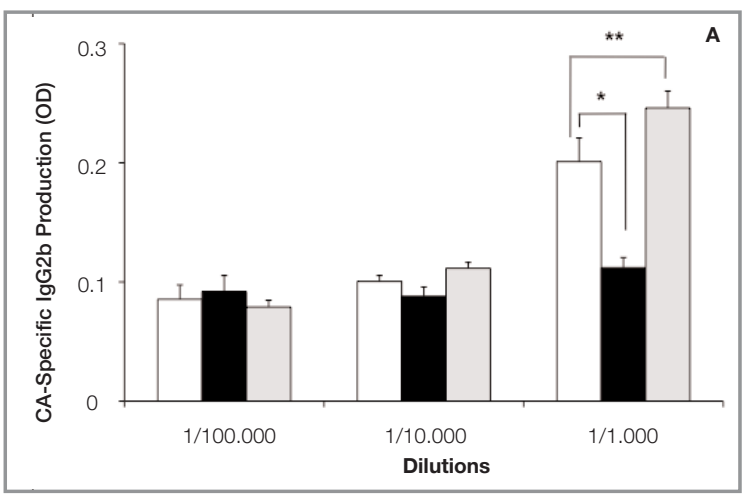

responses. We found that both glucans were effective in enhancing conalbumin specific antibody responses. However, S. cerevisiae-derived B-glucan had a significant superior activity to the barley-derived Bglucan in both primary and secondary responses.

Immunomodulatory effects of B-glucans have been studied so far. Unfortunately, there are many contradictory reports in the literature about their immunomodulating activities. Probably these controversies have been emerging due to the studies of $\beta$-glucans with various physical and chemical properties, such as molecular weight, solubility and degree of branching. Although there is still no consensus on the basic structural requirements for biologic activity, it is known that the immunomodulatory effects of B-glucans are influenced by their chemical and physical features. ${ }^{5}$ To emphasize this issue, we investigated

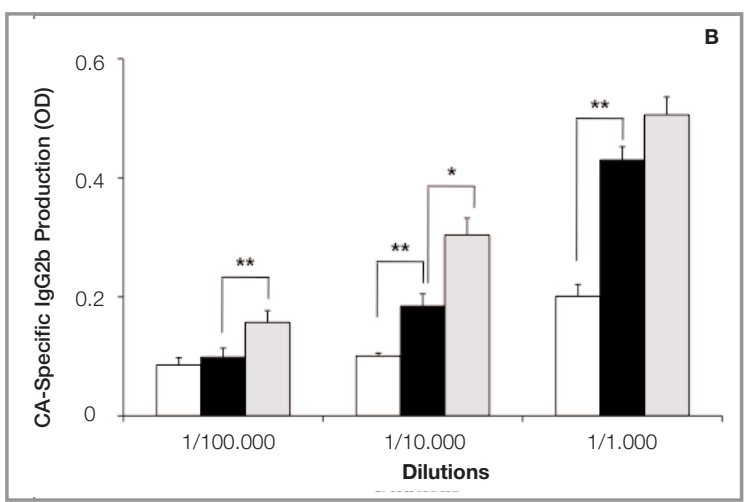

Figure 5. Adjuvant effects of soluble B-glucans on mucosal immune responses to conalbumin (CA). Adjuvant activity of S. cerevisiae-derived and barley-derived B-glucans that were co-administered at $1 \mu \mathrm{g}$ (A). Adjuvant activity of S. cerevisiae-derived and barley-derived B-glucan that were co-administered at $1000 \mu \mathrm{g}$ (B). ${ }^{*} \mathrm{p}<0.05$. White: None, Black: BG, Gray: SG. 
and compared two ß-glucans from two different sources. Our choice of B-glucans were both soluble but different in their side chain branching, i.e., $(1 \rightarrow 3)$, $(1 \rightarrow 6)-\beta$-D-glucan versus $(1 \rightarrow 3),(\quad 1 \rightarrow 4)-\beta$-D-glucans in Table 1. Molecular weight of the tested glucans was very close to each other. Conalbumin-specific IgM responses were enhanced by both glucans. However, $\beta$-glucan from S. cerevisae was significantly $(p<0.05)$ more efficient in enhancing specific IgM antibodies. Confirming our data, previous studies have shown that glucans from barley and yeast increased IgM and IgG responses..$^{15,16}$ In those studies, adjuvant activity of glucans either from barley or from yeast was investigated by independently working researchers who did not have the opportunity to compare the efficacy of barley- and yeast-derived glucans.

Several receptors have been identified since Czop proposed in 1986 that a cell surface molecule could mediate responses for ß-glucans. ${ }^{17}$ Now, we know that CR3 on neutrophils and natural killer cells plays very important roles in $\beta$-glucan-mediated immune responses. ${ }^{18-19}$ Additionally, other cell surface molecules such as dectin-1, lactosylceramide (CDw17), some scavenger receptors, and Toll-like receptor $2 / 6$ (TLR2/6) are among those for B-glucans. ${ }^{20-24}$ Binding of $\beta$-glucans to those receptors individually or in combinations initiates a serious of methabolic events

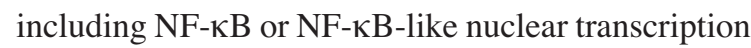
factor resulting in phagocytosis, degranulation of particules, and production of chemokines and cytokines depending on the activated cell type..$^{25-26}$ Recently, it was demonstrated that dectin-1 synergized with TLR2 to induce production of some cytokines such as TNF $\alpha$ and IL-12. ${ }^{24}$ Others have also shown that IL-2, IL-10 and IL-12 production of dendritic cells and macrophages was regulated by dectin-1 and TLR2. ${ }^{27}$ Probably cytokine combinations released following the induction of one or more of those $\beta$ glucan receptors affect the fate of antigen-driven humoral immune responses, e.g., altering magnitude of the responses or shaping isotype of antibodies to specific antigens. In the present study, we found that IgG1 was the major isotype of conalbumin-specific antibodies induced during the secondary humoral immune responses. B-glucan from S. cerevisiae increased specific antibodies of all isotypes tested whereas ß-glucan from barley did not. Based on our results, we speculated that differential adjuvant activity of barley- and yeast-derived B-glucans might result from their differential receptor specificity or preference and their differential binding properties to the specific B-glucan receptors mentioned above. Currently, we do not have data to support our speculation. However, our work continuous to test this speculation.

We found dose-effect relations in B-glucan-mediated activation of antigen specific humoral immune responses. We also tested $10 \mu \mathrm{g}$ and $100 \mu \mathrm{g}$ doses of glucans. Both glucans increased $\mathrm{IgG}$ responses in a dose dependent fashion at which yeast-derived glucan had always superior activity to the glucan from barley (data not shown). On the other hand, mice received $1 \mu \mathrm{g}$ barley derived glucan had lower IgG1, $\operatorname{IgG} 2 \mathrm{a}, \operatorname{IgG} 2 \mathrm{~b}$ and $\operatorname{IgA}$ levels than those of control animals that were injected with conalbumin only. At present, however, we do not know if there is any inhibitory pathway that would be induced by relatively low doses of $\beta$-glucans.

In conclusion, the present study represents an original investigation in terms of many perspectives, particularly in reflecting comparison of the magnitude of antigen specific humoral immune responses which were differentially modulated by the two soluble $\beta$ glucans. Here, we reported that $\mathrm{S}$. cerevisiae-derived B-glucan with $(1 \rightarrow 3),(1 \rightarrow 6)$ branches were superior in induction of specific antibody responses over barley $\beta$-glucan with $(1 \rightarrow 3),(1 \rightarrow 4)$ branches.

Acknowledgments: This work was supported by the grant No. 2003K120470-37 from the State Planning Organization (Devlet Planlama Teşkilatı: (DPT) of Türkiye.

\section{REFERENCES}

1. Hahinian S, Bussey H. B-1,6-Glucan synthesis in Saccharomyces cerevisiae. Mol Microbiol 35: 477489, 2000.

2. Lipke PN, Ovalle R. Cell wall architecture in yeast: New structure and challenges. J Bacteriol 180: 3735-4370, 1998.

3. Hrmova M, Banik M, Harvey AJ, et al. Polysaccharide hydrolyses in germinal barley and their role in the depolymerization of plant and fungal cell walls. Int J Biol Macromol 21: 67-72, 1997.

4. Descoix K, Ferrieres $V$, Jamois F, et al. Recent Progress in the field of $B-(1,3)$-Glucans and new applications. J Med Chem 6: 1341-1349, 2001. 
5. Brown GD, Dunn W. Fungal B-Glucans and mammalian immunity. Immunity 19: 311-315, 2003.

6. Shahinian S, Bussey H. B-1-6 glucan synthesis in Saccharomyches cerevisiae. Mol Microbiol 35: 477 489, 2000.

7. Yun $\mathrm{CH}$, Estrada A, Van Kessel A, et al. Beta-glucan, extracted from oat, enhances disease resistance against bacterial and parasitic infections. FEMS Immunol Med Microbiol 35: 67-75, 2003.

8. Liang J, Melican D, Cafro L, et al. Enhanced clearance of a multiple antibiotic resistant Staphylococcus aureus in rats treated with PGG-glucan is associated with increased leukocyte counts and increased neutrophil oxidative burst activity. Int J Immunopharmacol 20: 595-614, 1998.

9. Yun $\mathrm{CH}$, Estrada $\mathrm{A}$, Van Kessel $\mathrm{A}$, et al. Beta- $(1 \rightarrow 3$, $1 \rightarrow 4$ ) oat glucan enhances resistance to Eimeria vermiformis infection in immunosuppressed mice. Int $\mathrm{J}$ Parasitol 27: 329-337, 1997.

10. Wakshull E, Brunke-Reese D, Lindermuth J, et al. PGG-glucan, a soluble beta-(1,3)-glucan, enhances the oxidative burst response, microbicidal activity, and activates an NF-kappa B-like factor in human PMN: evidence for a glycosphingolipid beta-(1,3)-glucan receptor. Immunopharmacology 41: 89-107, 1999.

11. Yan J, Vetvicka $V, X i a ~ Y$, et al. Beta-glucan, a "specific" biologic response modifier that uses antibodies to target tumors for cytotoxic recognition by leukocyte complement receptor type 3 (CD11b/CD18). J Immunol 163: 3045-3052, 1999.

12. Hong F, Hansen RD, Yan J, et al. Betaglucan functions as an adjuvant for monoclonal antibody immunotherapy by recruiting tumoricidal granulocytes as killer cells. Cancer Res 63: 9023-9031, 2003.

13. Hong F, Yan J, Baran JT, et al. Mechanism by which orally administered beta-1,3-glucans enhance the tumoricidal activity of antitumor monoclonal antibodies in murine tumor models. J Immunol 173: 797-806, 2004.

14. Li B, Allendorf DJ, Hansen R, Marroquin J, Ding C, Cramer DE, Yan J. Yeast beta-glucan amplifies phagocyte killing of iC3b-opsonized tumor cells via complement receptor 3-Syk-phosphatidylinositol 3kinase pathway. J Immunol 177: 1661-1669, 2006.

15. Hoffman OA, Olson EJ, Limper AH. Fungal beta-glucans modulate macrophage release of tumor necrosis factor-alpha in response to bacterial lipopolysaccharide. Immunol Lett 37: 19-25, 1993.

16. Nakagawa $Y$, Ohno N, Murai T. Suppression by Candida albicans beta-glucan of cytokine release from activated human monocytes and from $T$ cells in the presence of monocytes. J Infect Dis 187: 710-713, 1993.

17. Czop JK. The role of b-glucan receptors on blood and tissue leukocytes in phagocytosis and metabolic activation. Pathol Immunopathol Res 5: 286-296, 1986.

18. Descroix $\mathrm{K}$, Ferrières $\mathrm{V}$, Jamois $\mathrm{F}$, et al. Recent progress in the field of beta- $(1,3)$-glucans and new applications. Mini Rev Med Chem 6: 1341-1349, 2006.
19. Harler MB, Reichner J. Increased neutrophil motility by beta-glucan in the absence of chemoattractant. Shock 16: 419-424, 2001.

20. Herre J, Gordon S, Brown GD. Dectin-1 and its role in the recognition of beta-glucans by macrophages. Mol Immunol 40: 869-876, 2004.

21. Zimmerman JW, Lindermuth J, Fish PA, et al. A novel carbohydrate-glycosphingolipid interaction between a beta-(1-3)-glucan immunomodulator, PGG-glucan, and lactosylceramide of human leukocytes. I Biol Chem 273: 22014-22020, 1998.

22. Hahn PY, Evans SE, Kottom TJ, et al. Pneumocystis carinii cell wall beta-glucan induces release of macrophage inflammatory protein-2 from alveolar epithelial cells via a lactosylceramide-mediated mechanism. J Biol Chem 278: 2043-2050, 2003.

23. Rice PJ, Kelley JL, Kogan G, et al. Human monocyte scavenger receptors are pattern recognition receptors for $(1 \rightarrow 3$ )-beta-D-glucans. J Leukoc Biol 72: 140-146, 2002.

24. Gantner BN, Simmons RM, Canavera SJ, et al. Collaborative induction of inflammatory responses by dectin-1 and Toll-like receptor 2. J Exp Med 197: 1107-1117, 2003

25. Williams DL, Ha T, Li C, et al. Inhibiting early activation of tissue nuclear factor-kappa B and nuclear factor interleukin 6 with $(1 \rightarrow 3$ )-beta-D-glucan increases longterm survival in polymicrobial sepsis. Surgery 126: 5465, 1999.

26. Adams DS, Pero SC, Petro JB, et al. PGG-Glucan activates NF-kappaB-like and NF-IL-6-like transcription factor complexes in a murine monocytic cell line. J Leukoc Biol 62: 865-873, 1999.

27. Rogers NC, Slack EC, Edwards AD, et al. Syk-dependent cytokine induction by Dectin-1 reveals a novel pattern recognition pathway for $\mathrm{C}$ type lectins. Immunity 22: 507-517, 2005.

\section{Correspondence}

Dr. Emin Ümit BAĞRIAÇIK

Gazi Üniversitesi Tıp Fakültesi

İmmünoloji Bölümü

Beşevler, 06500

Ankara / TURKEY

Tel: (+90.544) 3705770

Fax: (+90.312) 2124647

e-mail: eubagriacik@yahoo.com 